\title{
Crustal heat production and estimate of terrestrial heat flow in central East Antarctica, with implications for thermal input to the East Antarctic ice sheet
}

\author{
John W. Goodge \\ Department of Earth and Environmental Sciences, University of Minnesota, Duluth, MN 55812, USA \\ Correspondence: John Goodge (jgoodge@d.umn.edu) \\ Received: 5 July 2017 - Discussion started: 14 August 2017 \\ Revised: 10 November 2017 - Accepted: 5 January 2018 - Published: 8 February 2018
}

\begin{abstract}
Terrestrial heat flow is a critical first-order factor governing the thermal condition and, therefore, mechanical stability of Antarctic ice sheets, yet heat flow across Antarctica is poorly known. Previous estimates of terrestrial heat flow in East Antarctica come from inversion of seismic and magnetic geophysical data, by modeling temperature profiles in ice boreholes, and by calculation from heat production values reported for exposed bedrock. Although accurate estimates of surface heat flow are important as an input parameter for ice-sheet growth and stability models, there are no direct measurements of terrestrial heat flow in East Antarctica coupled to either subglacial sediment or bedrock. As has been done with bedrock exposed along coastal margins and in rare inland outcrops, valuable estimates of heat flow in central East Antarctica can be extrapolated from heat production determined by the geochemical composition of glacial rock clasts eroded from the continental interior. In this study, $\mathrm{U}, \mathrm{Th}$, and $\mathrm{K}$ concentrations in a suite of Proterozoic (1.2-2.0 Ga) granitoids sourced within the Byrd and Nimrod glacial drainages of central East Antarctica indicate average upper crustal heat production $\left(H_{\mathrm{o}}\right)$ of about $2.6 \pm 1.9 \mu \mathrm{W} \mathrm{m}^{-3}$. Assuming typical mantle and lower crustal heat flux for stable continental shields, and a length scale for the distribution of heat production in the upper crust, the heat production values determined for individual samples yield estimates of surface heat flow $\left(q_{\mathrm{o}}\right)$ ranging from 33 to $84 \mathrm{~mW} \mathrm{~m}^{-2}$ and an average of $48.0 \pm 13.6 \mathrm{~mW} \mathrm{~m}^{-2}$. Estimates of heat production obtained for this suite of glacially sourced granitoids therefore indicate that the interior of the East Antarctic ice sheet is underlain in part by Proterozoic continental lithosphere with an average surface heat flow, providing constraints on both geodynamic history and ice-
\end{abstract}

sheet stability. The ages and geothermal characteristics of the granites indicate that crust in central East Antarctica resembles that in the Proterozoic Arunta and Tennant Creek inliers of Australia but is dissimilar to other areas like the Central Australian Heat Flow Province that are characterized by anomalously high heat flow. Age variation within the sample suite indicates that central East Antarctic lithosphere is heterogeneous, yet the average heat production and heat flow of four age subgroups cluster around the group mean, indicating minor variation in the thermal contribution to the overlying ice sheet from upper crustal heat production. Despite these minor differences, ice-sheet models may favor a geologically realistic input of crustal heat flow represented by the distribution of ages and geothermal characteristics found in these glacial clasts.

\section{Introduction}

Heat production and heat flow are fundamental characteristics of continental crust (Rudnick and Fountain, 1995). Together they provide important constraints on the thermal and petrogenetic history of cratonic lithosphere, and heat flow is an indicator of modern geodynamic environments. The Antarctic lithosphere is uniquely important because it underlies Earth's largest ice caps, including numerous subglacial lakes, and it is critical in governing the thermal state and mechanical stability of overlying ice (Pollard et al., 2005; Jamieson and Sugden, 2008; Van Liefferinge and Pattyn, 2013; Schroeder et al., 2014). Terrestrial heat flow in Antarctica has a strong influence on basal ice temperatures, amount 
of basal ice at its pressure melting point, and the formation of liquid water, all of which affect basal ice conditions, mechanical properties of glacial bed material, degree of basal sliding, erosional effectiveness, and the distribution of hydrologic networks and subglacial lakes (e.g., Siegert, 2000; Pollard et al., 2005; Pollard and DeConto, 2009). Despite its importance in governing ice-sheet mass balance - and therefore as an input parameter for ice-sheet growth and stability models - only a few estimates of conductive heat flow are available from measurements in subglacial sediment or from temperature profiles in Antarctic ice (e.g., Begeman et al., 2017; Fischer et al., 2013). This is particularly problematic for East Antarctica, where the ice cap exceeds $4 \mathrm{~km}$ in thickness in many areas. In order to develop accurate models of past ice-sheet behavior and forward models of ice-sheet stability, it is therefore crucial to have good estimates of terrestrial heat flow from East Antarctica.

Continent-wide models for terrestrial heat flow come from both seismological and satellite magnetic data. To address a lack of direct heat flow measurements in Antarctica, Shapiro and Ritzwoller (2004) modeled surface heat flow by first correlating seismic velocity data from the crust and upper mantle in regions of known heat flow, and then extrapolating these results to a seismic model of Antarctic lithosphere. Over a broad region of East Antarctica they estimated surface heat flow to be notably low, uniform, and similar to other old cratons (mostly $35-60 \mathrm{~mW} \mathrm{~m}^{-2}$, with a mean estimate for East Antarctica of $57 \mathrm{~mW} \mathrm{~m}^{-2}$ ). Similarly, An et al. (2015) used a 3-D S-wave velocity model to construct temperature profiles for Antarctic lithosphere, from which they derived an average surface heat flux of $47 \mathrm{~mW} \mathrm{~m}^{-2}$ for the central Gamburtsev Subglacial Mountains region in East Antarctica. Fox Maule et al. (2005) used satellite magnetic data to model the depth to Curie temperature and then inverted the resulting thermal profile to generate a distribution of heat flow (see also Purucker, 2012); this modeling likewise predicted heat flow in East Antarctica to be similar to the results obtained from seismology, with an average heat flux of $50-60 \mathrm{~mW} \mathrm{~m}^{-2}$ in the central part of East Antarctica. In order to evaluate areas that may preserve very old ice, generally requiring relatively thick, slowmoving ice under cold conditions with low basal heat flux, Van Liefferinge and Pattyn (2013) derived an average distribution of heat flow from a simple mean of existing geophysical models (Fig. 1); this continent-wide synopsis highlights a relatively uniform pattern of low heat flow in East Antarctica (mostly $<55 \mathrm{~mW} \mathrm{~m}^{-2}$ ). Using a thermal model that assumes basal ice temperatures above Antarctic subglacial lakes are equal to the pressure-melting point, Siegert (2000) estimated geothermal heat flow to vary between 37 and $65 \mathrm{~mW} \mathrm{~m}^{-2}$, although most estimates for East Antarctica are $<60 \mathrm{~mW} \mathrm{~m}^{-2}$. In general terms, these different models, despite coarse kernel size, are consistent with one another and indicate heat flow in most of East Antarctica between about 35 and $60 \mathrm{~mW} \mathrm{~m}^{-2}$.

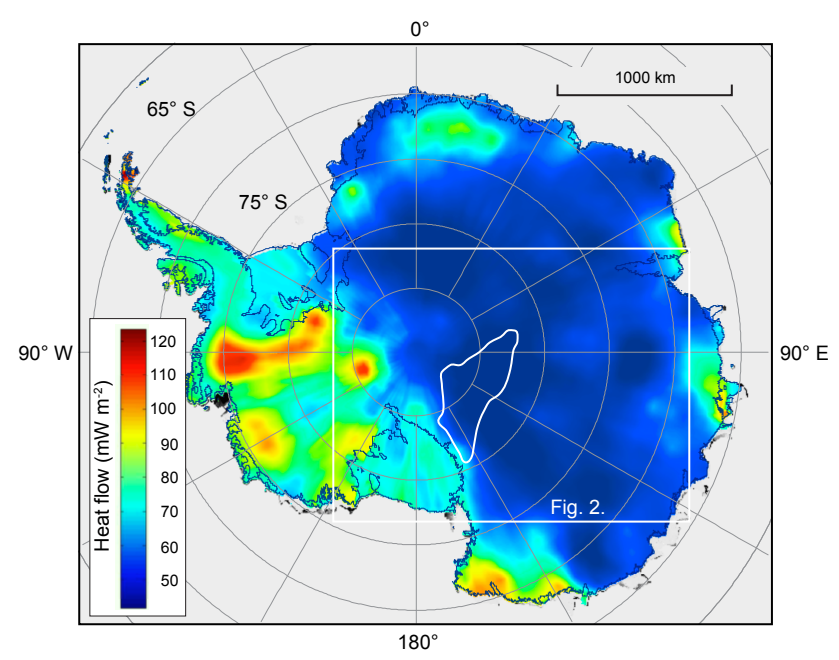

Figure 1. Terrestrial heat flow in Antarctica, from the mean geothermal heat flux model of Van Liefferinge and Pattyn (2013), which averages heat flow determined from multiple geophysical data sets. White box shows area of Fig. 2, including glacial drainage sourcing bedrock igneous rock clasts (white outline).

In addition to models based on remote geophysical observations, there are also some field-based estimates. Using a measured temperature profile in the EPICA ice borehole at Dome C, Fischer et al. (2013) derived a geothermal heat flux of about $54 \mathrm{~mW} \mathrm{~m}^{-2}$ by fitting a model of heat flow and basal ice melting to the thermal profile. A geological approach was taken by Carson et al. (2014), who derived heat flow using values for heat production estimated from the abundances of radioactive elements in crustal rocks sampled from outcrop near the Amery Ice Shelf (compiled by Carson and Pittard, 2012). From a coastal transect across rock exposures at Prydz Bay, the resulting profile indicates that heat flow in this area of Archean to Proterozoic igneous and metamorphic crust is highly variable over a distance of about $200 \mathrm{~km}$, ranging from an average of $31 \mathrm{~mW} \mathrm{~m}^{-2}$ in the Vestfold Hills to $44 \mathrm{~mW} \mathrm{~m}^{-2}$ in the Rauer Islands and $55-70 \mathrm{~mW} \mathrm{~m}^{-2}$ in the area of southern Prydz Bay. Locally, high heat-producing Cambrian granitoids indicate heat flow values as high as $\sim 85 \mathrm{~mW} \mathrm{~m}^{-2}$. Their model results thus show variable heat flow governed to first order by the age and type of crust represented and punctuated by heat production spikes contributed from Th-rich granitoids. Although much of the area underlying the Rauer Islands and Vestfold Hills has low heat flow $\left(<50 \mathrm{~mW} \mathrm{~m}^{-2}\right)$ typical of Proterozoic and Archean crust, Carson et al. (2014) emphasized that some early Paleozoic granites with anomalously high heat production can cause local elevation of heat flow $\left(>80 \mathrm{~mW} \mathrm{~m}^{-2}\right)$, as observed in the Central Australian Heat Flow Province (CAHFP; McLaren et al., 2003). Thus, spatially coarse models of heat flow based on geophysical data across East Antarctica indicate relatively typical continental values ranging from about 35 to $60 \mathrm{~mW} \mathrm{~m}^{-2}$, yet there are 


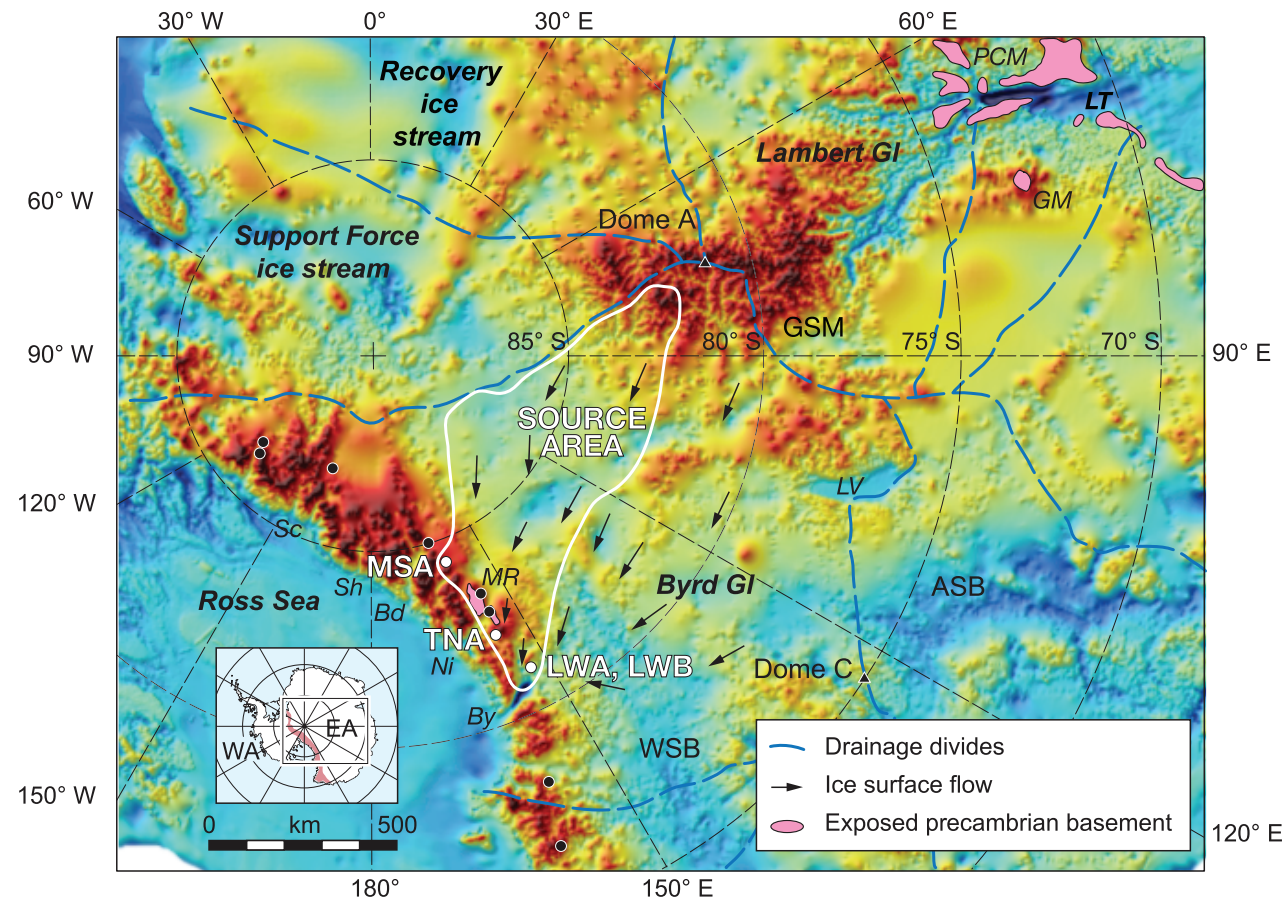

Figure 2. Map showing potential source areas for dated glacial igneous clasts, superimposed on the Bedmap2 subglacial topography of East Antarctica (Fretwell et al., 2013). Principal features are ice-sheet catchment areas (marked by thin blue drainage divides), ice flow directions in the broad Byrd Glacier drainage (arrows; Rignot et al., 2011), and areas of Precambrian basement exposure (pink). Composite source area (outlined by heavy white line) was determined from the ice flow fields that contribute ice to each of the sample sites (white circles). Other sampled sites are shown by black circles. Because transport distance is not known for any of the individual clasts, possible bedrock sources could lie anywhere between the sample sites and the top of the ice-shed overlapping the Gamburtsev Subglacial Mountains (GSM). Sample sites: LWA is Lonewolf Nunataks, MSA is Mt. Sirius, TNA is Turret Nunatak. Other abbreviations: ASB is Aurora Subglacial Basin, GM is Grove Mountains, LT is Lambert trough, LV is Lake Vostok, MR is Miller Range, PCM is Prince Charles Mountains, and WSB is Wilkes Subglacial Basin. Outlet glaciers: Bd is Beardmore, By is Byrd, Ni is Nimrod, Sc is Scott, and Sh is Shackleton.

some indications of locally elevated heat flow in areas underlain by high heat-producing granites.

Although there are no measurements of terrestrial heat flow obtained directly from subglacial sediment or rock in East Antarctica, rock clasts eroded from the continental interior and transported to the margin can provide insight into the subglacial geology and, therefore, heat production. In this paper, the concentrations of heat-producing elements in glacial igneous rock clasts provide a unique opportunity to assess heat flow in the deep continental interior. The major ice drainages in East Antarctica are marked by nearly radial flow away from central ice divides and domes toward the continental margin (Fig. 2), providing natural proxy samples of the continental interior by bedrock erosion during glacial flow (Peucat et al., 2002; Goodge et al., 2008, 2010, 2017). Unique among the major drainages, glacial ice in Byrd Glacier and related smaller drainages moves nonradially from the main ice divides because it is obstructed by the high-standing Transantarctic Mountains (peak elevations $>4000 \mathrm{~m}$ ). Ice flows through the mountains via channelized outlet glaciers, but it also ablates in areas where it ramps up against the mountain range (Whillans and Cassidy,
1983). Glacial moraines are formed both along the margins of the outlet glaciers and where ice is ablating, forming lag deposits adjacent to the mountains. As part of a study of East Antarctic crustal history, glacial moraines were sampled at sites between the Byrd and Beardmore glaciers (Fig. 2). Icevelocity fields show that material transported in the greater Byrd system may have been eroded from a broad area of central East Antarctica, potentially from near the upstream boundary along the major ice divide connecting Dome A and Dome C.

As proxies for subglacial geology, igneous clasts eroded from central East Antarctica and collected from moraines adjacent to the central Transantarctic Mountains were dated and analyzed geochemically for major and trace elements - including the major heat-producing elements $\mathrm{U}, \mathrm{Th}$, and $\mathrm{K}-$ yielding values of radiogenic heat production. Surface heat flow was then estimated by assuming mantle and lower crustal heat-flux contributions and a length scale for reduction in upper-crustal radiogenic heat production. The results indicate that heat production among most of the samples in this group is within the range expected for average continental crust and that terrestrial heat flow for a large region of 
central East Antarctica is like that commonly observed in Precambrian shield areas. Estimates from this analysis corroborate previous geophysical models of heat flow in East Antarctica and can be used as first-order constraints in icesheet and lithospheric thermal models.

\section{Glacial igneous clasts}

Glacial igneous rock clasts were collected as part of a separate study to obtain lithologic, petrologic, and isotopic information about the Precambrian crust of East Antarctica (Goodge et al., 2017). About a dozen sites were sampled where glacial moraines are exposed, extending $>1500 \mathrm{~km}$ along the length of the Transantarctic Mountains from the Convoy Range in southern Victoria Land to Strickland Nunatak near Reedy Glacier (Fig. 2). The original purpose of the clast sampling was to obtain a representative set of samples from the ice-covered East Antarctic craton in order to address questions of crustal age, composition, and Precambrian history by investigating their age and isotopic compositions. In the field, any rock clasts that represented potential cratonic basement were collected within an allotted ground time, thus providing an effectively randomized sample. Over 300 large individual clasts were obtained. For the previous study, five sites yielded the most useful samples; the other sites were dominated by clasts of Beacon Supergroup sediment or Ferrar dolerite eroded from the Transantarctic Mountains. A major effort was then undertaken to screen the crystalline clast samples by reconnaissance in situ U$\mathrm{Pb}$ geochronology in order to cull samples with Ross orogen ( $\sim 500 \mathrm{Ma}$ ) or younger ages in order to focus solely on the Precambrian crustal history of the shield interior. Analysis of the remaining suite of 22 samples included detailed petrography, mineral analysis, geochemical analysis, mineral separation, precise $\mathrm{U}-\mathrm{Pb}$ geochronology, $\mathrm{O}$-isotope analysis, and Hf-isotope analysis (see Goodge et al., 2017).

In this contribution, results are presented from samples collected at three sites for which geochemical data are available from dated Precambrian rock clasts - Lonewolf Nunataks (LWA and LWB), Mt. Sirius (MSA), and Turret Nunatak (TNA) (Fig. 2; Table 1). At Lonewolf Nunataks, elongate bands of distributed moraine and ice-matrix debris follow narrow flow lines related to ice movement along the southern margin of Byrd Glacier. This site, at the southern margin of Byrd Glacier, was the single most productive site sampled, presumably because the Byrd ice stream is among the fastest outlet glaciers traversing the Transantarctic Mountains and capable of significant glacial erosion. It is numerically oversampled compared to other sites (Table 1), yet it contains the full range of clast ages obtained for the whole suite $(1.2-2.0 \mathrm{Ga})$ so is likely to be representative of the craton interior. Sites at Turret Nunatak and Mt. Sirius are dominated by Gondwanide debris, but they also yielded a small number of distinctive crystalline clasts. Together, these sites comprise a suite of pre-Ross igneous samples with ages ranging from about 1.2 to $2.0 \mathrm{Ga}$. The igneous clasts consist mainly of intermediate to felsic igneous rocks that represent magmatic components of the ice-covered East Antarctic craton. They are granitic to granodioritic in composition and contain hornblende, biotite and/or muscovite; some samples are two-mica granitoids of peraluminous composition. Detailed sample descriptions are provided by Goodge et al. (2017), including petrographic features, geochemical data, cathodoluminescence (CL) images of zircons, and zircon isotopic data ( $\mathrm{U}-\mathrm{Pb}, \mathrm{O}$, and $\mathrm{Lu}-\mathrm{Hf})$.

Zircon $\mathrm{U}-\mathrm{Pb}$ ages from this suite of glacially transported granitoid clasts show that the crust in central East Antarctica was formed by a series of magmatic events at $\sim 2.01,1.88-$ $1.85, \sim 1.79, \sim 1.57,1.50-1.41$, and 1.20-1.06 Ga (Goodge et al., 2008, 2010, 2012, 2017). The dominant granitoid populations are ca. $1.85,1.45$ and $1.20-1.06 \mathrm{Ga}$. None of these igneous ages are known from the limited outcrop in the region. Samples of metamorphic rock clasts from the same moraines have similar Proterozoic ages ranging from about 1.1 to $1.9 \mathrm{Ga}$ (Goodge et al., 2010; Nissen et al., 2013). When compared to nearby mountain outcrops, the types and ages of these samples indicate that the crust of central East Antarctica comprises plutonic and metamorphic rocks unlike those seen in the central Transantarctic Mountains (Nimrod Complex ages of ca. 3.1, 2.5, and 1.7 Ga; Goodge et al., 2001; Goodge and Fanning, 2016). Likewise, they are different from igneous and metamorphic rocks exposed at the Adélie Land coast (ages of ca. 2.4 and 1.7 Ga; Oliver and Fanning, 1997 ), although one population is similar in age to $\sim 1.6 \mathrm{Ga}$ glacial clasts sampled by Peucat et al. (2002). As shown in Fig. 2, the glacially eroded igneous clasts discussed here may also sample the Gamburtsev Subglacial Mountains, which is thought to have nucleated growth of the East Antarctic Ice Sheet (DeConto and Pollard, 2003; Bo et al., 2009; Rose et al., 2013).

It is important to note that only with high-quality age data for this igneous clast suite is it possible to constrain potential heat production and heat flow within the west-central interior of East Antarctica. In the absence of age data, the origin of glacially transported clasts is largely unconstrained and a large fraction of any such samples could be sourced from the Ross orogen or from younger Beacon cover in the Transantarctic Mountains, neither of which inform subglacial heat flow in the craton interior. Thus, simply sampling moraines to obtain a large set of geochemical data without geochronological control may yield misleading results. Although it would be beneficial to have a larger sample set taken from a potentially wider catchment area, this would require substantial logistical and analytical resources beyond those employed by this initial reconnaissance study. 
Table 1. Estimates of $H_{\mathrm{o}}$ and $q_{\mathrm{o}}$ for igneous clast samples, central East Antarctica.

\begin{tabular}{|c|c|c|c|c|c|c|c|c|c|c|c|}
\hline Sample ${ }^{\mathrm{a}}$ & $\begin{array}{l}\text { Age } \\
\text { (Ma) }\end{array}$ & $\begin{array}{r}\mathrm{U} \\
(\mathrm{ppm})\end{array}$ & $\begin{array}{r}\mathrm{Th} \\
(\mathrm{ppm})\end{array}$ & $\mathrm{Th} / \mathrm{U}$ & $\begin{array}{r}\mathrm{K}_{2} \mathrm{O} \\
(\mathrm{wt} \%)\end{array}$ & $\begin{array}{r}\mathrm{K} \\
(\mathrm{wt} \%)\end{array}$ & $\mathrm{K} / \mathrm{U}$ & $\begin{array}{r}\text { Density } \\
\left(\mathrm{g} \mathrm{cm}^{-3}\right)\end{array}$ & $\begin{array}{r}H_{\mathrm{o}}(1)^{\mathrm{b}} \\
\left(\mu \mathrm{W} \mathrm{m}^{-3}\right)\end{array}$ & $\begin{array}{r}H_{\mathrm{O}}(2)^{\mathrm{b}} \\
\left(\mu \mathrm{W} \mathrm{m}^{-3}\right)\end{array}$ & $\left(\mathrm{mW} \mathrm{m}^{-2}\right)^{q_{\mathrm{o}}^{\mathrm{c}}}$ \\
\hline 10LWA-13.1 & 1204 & 5.7 & 27.7 & 4.9 & 3.80 & 3.15 & 0.55 & 2.7 & 3.81 & 3.79 & 56.8 \\
\hline 10LWA-11.1 & 1213 & 2.5 & 32.9 & 13.2 & 4.72 & 3.92 & 1.57 & 2.7 & 3.43 & 3.40 & 54.1 \\
\hline 10MSA-2.3 & 1410 & 0.2 & 38.0 & 190.0 & 7.26 & 6.03 & 30.13 & 2.7 & 3.43 & 3.35 & 54.1 \\
\hline 10TNA-1.1 & 1430 & 1.2 & 18.5 & 15.4 & 4.39 & 3.64 & 3.03 & 2.7 & 2.04 & 1.98 & 43.9 \\
\hline 10LWA-6.5 & 1432 & 2.7 & 15.8 & 5.9 & 8.16 & 6.77 & 2.51 & 2.7 & 2.59 & 2.46 & 47.9 \\
\hline 10LWB-4.3 & 1448 & 1.2 & 11.4 & 9.5 & 5.76 & 4.78 & 3.99 & 2.7 & 1.66 & 1.57 & 41.2 \\
\hline 10LWB-3.8 & 1470 & 1.2 & 5.8 & 4.8 & 4.19 & 3.48 & 2.90 & 2.7 & 1.12 & 1.05 & 37.2 \\
\hline 10LWA-20.1 & 1486 & 1.2 & 8.6 & 7.2 & 2.35 & 1.95 & 1.63 & 2.7 & 1.14 & 1.11 & 37.4 \\
\hline 10MSA-3.5 & 1508 & 0.0 & 1.5 & - & 1.57 & 1.30 & - & 2.7 & 0.25 & 0.23 & 30.9 \\
\hline 10LWA-6.4 & 1570 & 6.4 & 26.9 & 4.2 & 5.65 & 4.69 & 0.73 & 2.7 & 4.11 & 4.05 & 59.0 \\
\hline 10LWA-14.1 & 1786 & 5.4 & 41.9 & 7.8 & 5.77 & 4.79 & 0.89 & 2.7 & 4.93 & 4.89 & 65.0 \\
\hline 10LWB-4.5 & 1848 & 0.5 & 13.4 & 26.8 & 3.89 & 3.23 & 6.46 & 2.7 & 1.45 & 1.39 & 39.6 \\
\hline 10LWA-6.3 & 1850 & 0.0 & 98.3 & - & 5.38 & 4.46 & - & 2.7 & 7.49 & 7.54 & 83.6 \\
\hline 10LWA-7.1 & 1854 & 0.6 & 18.2 & 30.3 & 6.83 & 5.67 & 9.44 & 2.7 & 2.09 & 1.99 & 44.3 \\
\hline 10LWB-4.1 & 1865 & 1.2 & 10.4 & 8.7 & 4.92 & 4.08 & 3.40 & 2.7 & 1.51 & 1.44 & 40.1 \\
\hline 10MSA-3.3 & 1876 & 1.9 & 1.0 & 0.5 & 2.29 & 1.90 & 1.00 & 2.7 & 0.78 & 0.74 & 34.7 \\
\hline 10LWA-10.1 & 2010 & 2.9 & 51.3 & 17.7 & 0.73 & 0.60 & 0.21 & 2.7 & 4.47 & 4.54 & 61.6 \\
\hline 10LWA-8.1 & 2015 & 0.8 & 4.9 & 6.1 & 0.53 & 0.44 & 0.55 & 2.7 & 0.61 & 0.61 & 33.4 \\
\hline Mean & & 2.0 & 23.7 & 22.1 & 4.34 & 3.60 & 4.31 & & 2.61 & 2.56 & 48.0 \\
\hline SD & & 2.0 & 23.6 & - & 2.18 & 1.81 & - & & 1.86 & 1.89 & 13.6 \\
\hline Prot. average $\mathrm{d}^{\mathrm{d}}$ & & 2.4 & 10.0 & 3.63 & & 2.39 & 0.98 & & 3.83 & 3.83 & \\
\hline
\end{tabular}

a Samples collected at the following sites: LWA and LWB are Lonewolf Nunataks (two sites), MSA is Mt. Sirius, and TNA is Turret Nunatak (see Goodge et al., 2017).

${ }^{\mathrm{b}}$ Heat production $\left(H_{\mathrm{O}}\right)$ was calculated from geochemical analysis in two ways. Method 1 uses the relation $H_{\mathrm{O}}=10^{-2} \rho(9.67[\mathrm{U}]+2.63[\mathrm{Th}]+3.48[\mathrm{~K}])$ using values after Rybach (1988) and Hasterok and Chapman (2011). Method 2 uses the relation $H_{\mathrm{O}}=\rho\left(0.9928[\mathrm{U}] \mathrm{H}\left(\mathrm{U}^{238}\right)+0.0071[\mathrm{U}] \mathrm{H}\left(\mathrm{U}^{235}\right)+[\mathrm{Th}] \mathrm{H}(\mathrm{Th})+1.19 \times 10^{-4}[\mathrm{~K}] \mathrm{H}\left(\mathrm{K}^{40}\right)\right)$, after Turcotte and Schubert (2014). Both assume an average density $(\rho)$ for granitic rocks of $2.7 \mathrm{~g} \mathrm{~cm}^{-3}$.

${ }^{\mathrm{c}}$ Surface heat flow $\left(q_{\mathrm{o}}\right)$ determined from $q_{\mathrm{o}}=q_{\mathrm{m}}+q_{\mathrm{r}}+\left(H_{\mathrm{o}} h_{\mathrm{r}}\right)$ (Turcotte and Schubert, 2014). Moho heat flux $\left(q_{\mathrm{m}}\right)$ is assumed to be $14 \mathrm{~mW} \mathrm{~m}{ }^{-2}$ for stable continental shield areas (Mareschal and Jaupart, 2013; Jaupart et al., 2016), lower crustal heat flow $\left(q_{\mathrm{r}}\right)$ is assumed to be $15 \mathrm{~mW} \mathrm{~m}^{-2}$, and length scale for reduction in heat production with depth $\left(h_{\mathrm{r}}\right)$ is assumed to be $7.3 \mathrm{~km}$.

d Artemieva et al. (2017).

\section{Analytical methods}

Bulk-rock X-ray fluorescence (XRF) and inductively coupled plasma mass spectrometry (ICPMS) analyses of major and trace element compositions were completed in the GeoAnalytical Lab at Washington State University (Goodge et al., 2017). Prior to analysis, fresh chips of each sample were handpicked and a standard amount (approximately $28 \mathrm{~g}$ ) was ground in a swing mill with tungsten carbide surfaces for $2 \mathrm{~min}$. For XRF analysis of major elements, $3.5 \mathrm{~g}$ of sample powder was weighed in a plastic mixing jar with $7 \mathrm{~g}$ of spec pure dilithium tetraborate $\left(\mathrm{Li}_{2} \mathrm{~B}_{4} \mathrm{O}_{7}\right)$. The mixed powders were emptied into graphite crucibles and loaded into a muffle furnace for fusion at $1000^{\circ} \mathrm{C}$. After being removed from the oven to cool, each bead was reground in the swing mill and the resulting glass powders were replaced in the graphite crucibles and refused for $5 \mathrm{~min}$, then cooled to form a glass bead. Their lower flat surfaces were then ground on 600 silicon carbide grit and finished briefly on a glass plate to remove any metal from the grinding wheel. The concentrations of 29 elements in the unknown samples were measured on a ThermoARL Advant'XP+ sequential X-ray fluo- rescence spectrometer by comparing the X-ray intensity for each element with the intensity obtained from USGS standard samples (PCC-1, BCR-1, BIR-1, DNC-1, W-2, AGV-1, GSP-1, G-2, and STM-1), using the values recommended by Govindaraju (1994) and beads of pure vein quartz used as blanks for all elements except $\mathrm{Si}$. Twenty standard beads are routinely run and used for recalibration approximately once every 3 weeks or after the analysis of about 300 unknowns. The intensities for all elements were corrected for line interference and absorption effects due to all the other elements using the fundamental parameter method.

For trace elements, powdered samples were mixed with $2 \mathrm{~g}$ of $\mathrm{Li}_{2} \mathrm{~B}_{4} \mathrm{O}_{7}$ flux, placed in a carbon crucible and fused at $1000^{\circ} \mathrm{C}$ in a muffle furnace for $30 \mathrm{~min}$. After cooling, the resultant fusion bead was briefly ground in a carbon-steel ring mill and a $250 \mathrm{mg}$ portion was weighed into a $30 \mathrm{~mL}$, screwtop Teflon PFA vial for dissolution in water, $\mathrm{HNO}_{3}, \mathrm{H}_{2} \mathrm{O}_{2}$, and $\mathrm{HF}$ and warmed on a hot plate until a clear solution was obtained. Samples were then diluted to a final weight of $60 \mathrm{~g}$ with de-ionized water. Solutions were analyzed for 27 elements on an Agilent model 4500 ICPMS and were diluted an additional $10 \times$ at the time of analysis using Agilent's 
Integrated Sample Introduction System (ISIS). This yielded a final dilution factor of $1: 4800$ relative to the amount of sample fused. Instrumental drift was corrected using Ru, In, and $\mathrm{Re}$ as internal standards and applying a linear interpolation between In and Re to compensate for mass-dependent differences in the rate and degree of instrumental drift. Isobaric interferences of rare earth and other oxides were optimized with correction factors using mixed-element solutions. Standardization was accomplished by analyzing duplicates of three in-house rock standards interspersed within each batch of 18 unknowns.

\section{Heat production and estimated heat flow}

\subsection{Sample geochemical characteristics}

Major, trace and rare-earth element geochemical data show that the granitoid samples are $\mathrm{Si}$-rich with $>65 \mathrm{wt} \% \mathrm{SiO}_{2}$, and many have $\mathrm{SiO}_{2}$ of 70-75 wt \%. Trace-element abundances are enriched with light rare-earth elements (LREEs) and depleted in heavy rare-earth elements (HREEs) relative to chondrites, and they are enriched in large ion lithophile (LIL) elements and slightly depleted in high field-strength (HFS) elements relative to mid-ocean ridge basalt (MORB). Their trace and rare-earth element signatures are quite similar to modern continental-margin magmatic arc systems (e.g., Cascades, Andes) or evolved volcanic arcs, and they show very similar patterns and abundances as magmas interacting with thick crust (e.g., Davidson et al., 1990, 1991; Wörner et al., 1994). Some of the samples resemble Si-rich, peraluminous leucogranites found in regions of overthickened continental crust (Frost et al., 2001). In broad terms, then, the trace-element compositions indicate that the melts that produced these igneous rocks interacted with thick, evolved continental crust, but that they are dissimilar generally from intraplate granitoids.

\subsection{Heat-producing elements}

The concentrations of the heat-producing elements $\mathrm{U}$, Th, and $\mathrm{K}$ in 18 granitoid samples are listed in Table 1. The concentration of $\mathrm{U}$ is generally low, ranging up to about $6 \mathrm{ppm}$ $($ mean $=2.0)$. Thorium ranges widely, from 1 to $98 \mathrm{ppm}$ $($ mean $=23.7)$, and $\mathrm{K}$ similarly varies from 0.5 to $8 \mathrm{wt} \%$ $\mathrm{K}_{2} \mathrm{O}$ (mean =4.34). Most of the samples have normal concentrations of $\mathrm{U}$, Th, and $\mathrm{K}$ that are quite similar to the ranges expected for Proterozoic and Archean granites (Artemieva et al., 2017), and ratios of $\mathrm{Th} / \mathrm{U}$ and $\mathrm{K} / \mathrm{U}$ are mostly in the range typical of Middle and Late Proterozoic granites (Table 1). Most samples show a linear relationship between Th / U and K/U (Fig. 3), indicating that the samples as a group show coherent geochemical behavior and no evidence of significant mobilization of their heat-producing elements.

Three samples show some notable variations, however. Sample 10MSA-2.3 is a red-colored biotite leucogranite with
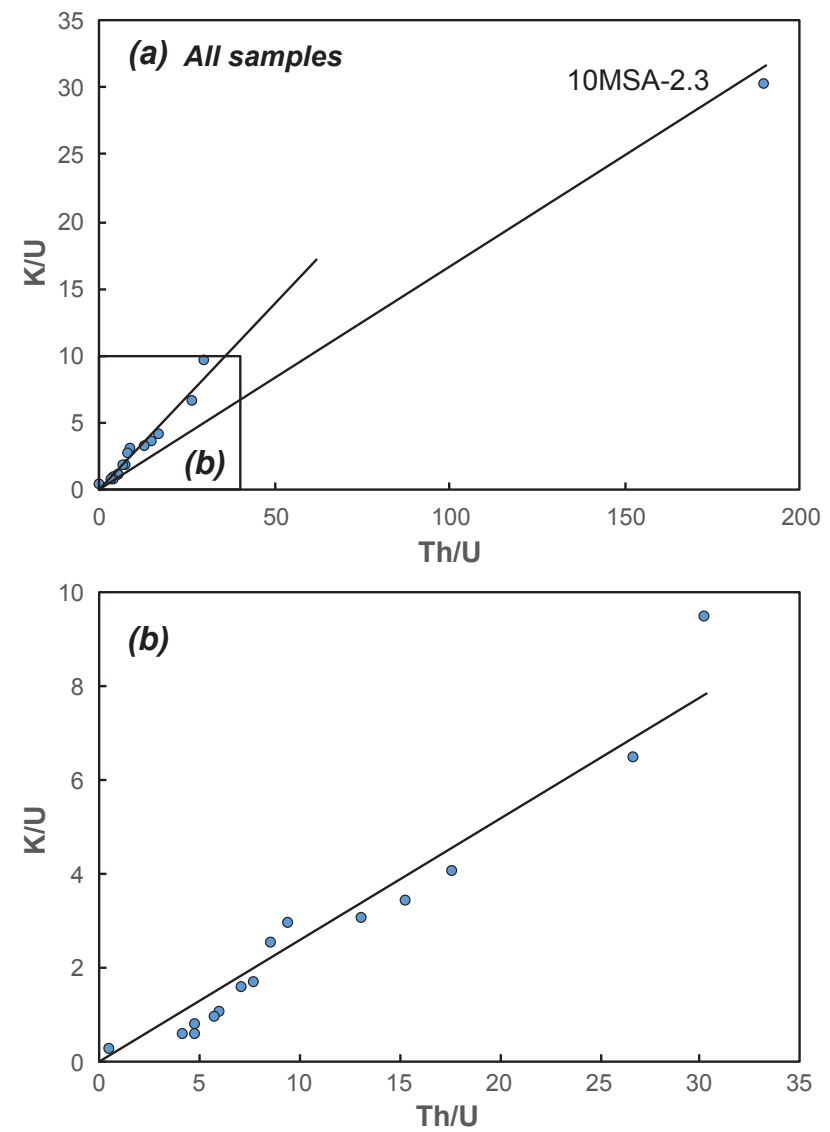

Figure 3. (a) Plot of Th / U vs. K / U in glacial igneous clasts, with detail in (b) that excludes sample 10MSA-2.3. Linear regression in (b) was calculated for all samples minus sample 10MSA-2.3.

very low $\mathrm{U}$ and moderately high $\mathrm{Th}$ and $\mathrm{K}$, which results in highly elevated ratios of $\mathrm{Th} / \mathrm{U}$ and $\mathrm{K} / \mathrm{U}$; these high ratios are chiefly a result of the low $\mathrm{U}$ concentration in this sample. It appears weathered on the surface but has a zircon $\delta^{18} \mathrm{O}=8.2 \%$ (Goodge et al., 2017), indicating a crustal melt origin with no hydrothermal alteration in the source area. Sample 10MSA-3.5 is a foliated Ms-Bt leucogranite with undetectable $\mathrm{U}$ and low $\mathrm{Th}$ and $\mathrm{K}$, resulting in an abnormally low concentration of heat-producing elements. This sample has a zircon $\delta^{18} \mathrm{O}=5.1 \%$, indicating a mantle melt origin. Sample 10LWA-6.3 has undetectable U, high Th, and average $\mathrm{K}$, resulting in an anomalously high value of heat production as a result of very high Th. This sample is a layered biotite granite with zircon $\delta^{18} \mathrm{O}=7.1 \%$, indicating a crustal melt origin with no hydrothermal alteration in the source area.

\subsection{Heat production}

The geochemical compositions of igneous rocks can be used to determine crustal heat production based on their concentrations of radioactive elements. Heat production $\left(H_{\mathrm{o}}\right)$ was 
calculated for these clast samples based on rock density and concentrations of the heat-producing elements $\mathrm{U}, \mathrm{Th}$, and $\mathrm{K}$ by applying two different algorithms:

$$
\begin{aligned}
& H_{\mathrm{O}}=10^{-2} \rho(9.67[U]+2.63[\mathrm{Th}]+3.48[K]), \\
& H_{\mathrm{O}}=\rho\left(0.9928[U] H\left({ }^{238} \mathrm{U}\right)+0.0071[U] H\left({ }^{235} \mathrm{U}\right)\right. \\
& \left.\quad+[T h] H(\mathrm{Th})+1.19 \times 10^{-4}[K] H\left({ }^{40} \mathrm{~K}\right)\right),
\end{aligned}
$$

where $H_{\mathrm{O}}$ is surface heat production $\left(\mu \mathrm{W} \mathrm{m}{ }^{-3}\right), \rho$ is density $\left(\mathrm{kg} \mathrm{m}^{-3}\right),[U]$ is the concentration of $\mathrm{U}(\mathrm{ppm}),[T h]$ is the concentration of $\mathrm{Th}(\mathrm{ppm}),[K]$ is the concentration of $\mathrm{K}_{2} \mathrm{O}$ (wt \%), $\mathrm{H}\left({ }^{238} \mathrm{U}\right)$ is the heat production from the isotope ${ }^{238} \mathrm{U}$ $\left(9.37 \times 10^{-5} \mathrm{~W} \mathrm{~kg}^{-1}\right), \mathrm{H}\left({ }^{235} \mathrm{U}\right)$ is the heat production from the isotope ${ }^{235} \mathrm{U}\left(5.69 \times 10^{-4} \mathrm{~W} \mathrm{~kg}^{-1}\right), H(\mathrm{Th})$ is the heat production from the isotope ${ }^{232} \mathrm{Th}\left(2.69 \times 10^{-5} \mathrm{~W} \mathrm{~kg}^{-1}\right)$, and $H\left({ }^{40} \mathrm{~K}\right)$ is the heat production from the isotope ${ }^{40} \mathrm{~K}$ $\left(2.79 \times 10^{-5} \mathrm{~W} \mathrm{~kg}^{-1}\right)$. Method 1 was calculated as in Eq. (1) from the formula of Rybach $(1976,1988)$ using values from Hasterok and Chapman (2011). Method 2 uses the formulation of Turcotte and Schubert (2014) as given in Eq. (2). Both methods are included here for the purposes of comparison and so the values can be compared with results from other areas that use either of the calculations. Density $(\rho)$ was assumed to be $2.7 \times 10^{3} \mathrm{~kg} \mathrm{~m}^{-3}$ in all cases. Using Method 1, the igneous clast compositions yield estimates of heat production ranging from 0.25 to $7.49 \mu \mathrm{W} \mathrm{m}^{-3}$, with an average of about $2.6 \mu \mathrm{W} \mathrm{m}^{-3}$ and $1 \sigma$ standard deviation of $1.9 \mu \mathrm{W} \mathrm{m}^{-3}$ (Table 1). Most of the variation observed in these samples comes from variations in concentrations of $U$ and Th. Method 2 gives quite similar results. It is notable that the two samples with both the highest and lowest calculated heat production (10MSA-3.5 and 10LWA-6.3) have anomalous concentrations of $U$ and/or $\mathrm{Th}$, suggesting that these may represent outliers that are not representative of crust in the glacial catchment area.

Estimates of heat production versus age are plotted in Fig. 4. Compared to an average value of surface heat production in stable continental shield regions of $\sim 2 \mu \mathrm{W} \mathrm{m}{ }^{-3}$ (Jaupart et al., 2016), most of the Antarctic clast samples are of similar magnitude, with 11 of 18 falling between 1 and $4 \mu \mathrm{W} \mathrm{m}^{-3}$. Some of the values are higher than those reported for other cratonic areas (e.g., Canadian Shield and Grenville orogen; Mareschal and Jaupart, 2013; Jaupart et al., 2016) and most are higher than the bulk upper crustal average of about $1.6 \mu \mathrm{W} \mathrm{m}^{-3}$ (Kemp and Hawkesworth, 2003; Jaupart et al., 2016). As a group, the granite clast values overlap a range of $1-3 \mu \mathrm{W} \mathrm{m}{ }^{-3}$ observed in granites globally (Artemieva et al., 2017), and their mean of about $2.6 \mu \mathrm{W} \mathrm{m}{ }^{-3}$ is quite similar to the global average granitic heat production of $2.5 \mu \mathrm{W} \mathrm{m}^{-3}$ (Rybach, 1976; Haenel et al., 1988). The glacial granite clasts overlap significantly with Proterozoic granites worldwide (Artemieva et al., 2017), with an average heat production of $3.83 \pm 2.14 \mu \mathrm{Wm}^{-3}$ (Fig. 4). Heat production from the clasts is comparable to estimates obtained

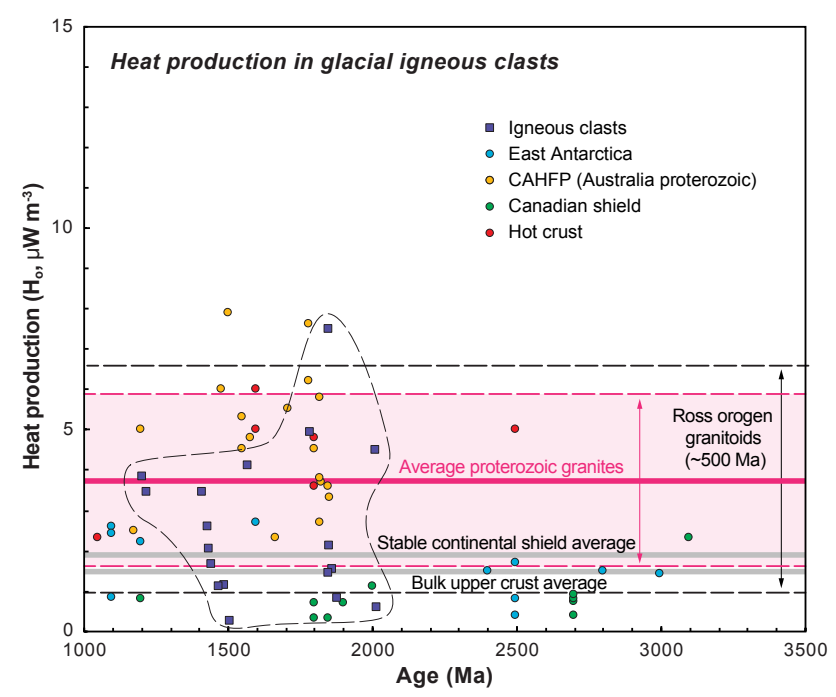

Figure 4. Plot of surface heat production $\left(H_{\mathrm{O}}\right)$ vs. age for igneous glacial clasts. Data are listed in Table 1. Range of heat production values in Ross orogen granites from unpublished data. For comparison, values are shown from East Antarctica (Carson and Pittard, 2012; Carson et al., 2014), the Central Australian Heat Flow Province (CAHFP; McLaren et al., 2003), the Canadian Shield (Mareschal and Jaupart, 2013; Jaupart et al., 2016), and areas of high heat production in stable continental provinces ("hot crust"; Mareschal and Jaupart, 2013; Jaupart et al., 2016). Average heat production in Middle and Late Proterozoic granites of about $3.8 \mu \mathrm{W} \mathrm{m}^{-3}$ are from Artemieva et al. (2017). Bulk upper crustal average of about 1.6 $\mu \mathrm{W} \mathrm{m}^{-3}$ from Kemp and Hawkesworth (2003).

from Archean and Paleoproterozoic bedrock exposed in the coastal region of southern Prydz Bay $\left(2.4-2.6 \mu \mathrm{W} \mathrm{m}^{-3}\right.$; Carson and Pittard, 2012; Carson et al., 2014). Four of the clasts give high values between 4.0 and $7.5 \mu \mathrm{W} \mathrm{m}^{-3}$, which are similar to global occurrences of crust characterized by high heat production (Mareschal and Jaupart, 2013; Jaupart et al., 2016) and exemplified by the Central Australian Heat Flow Province (Neumann et al., 2000; Sandiford and McLaren, 2002; McLaren et al., 2003). Nonetheless, all but two of the samples in this suite have heat production less than the mean for the CAHFP $\left(4.6 \mu \mathrm{W} \mathrm{m}^{-3}\right)$.

The variability in heat production shown by the data presented here resembles that observed in regions comprised of Precambrian shields or granitic batholiths and likely represents real heterogeneities in the source region. Although the precise distribution of heat-producing rocks in the source area from which these clast samples were eroded is not known, this group may collectively provide a qualitatively random sample that provides a means to assess the average heat production for a broad region of the continental interior. Compared to examples globally (Mareschal and Jaupart, 2013; Jaupart et al., 2016; Artemieva et al., 2017), the Proterozoic igneous rocks in this study indicate that heat production in central East Antarctica is like that of typical 
continental shield areas and demonstrably different from the anomalously warm region represented by the CAHFP. Geological and geophysical correlations between cratonic rocks in southern Australia (Gawler craton) and the Wilkes Land region of East Antarctica (e.g., Oliver and Fanning, 1997; Aitken et al., 2014; Goodge and Finn, 2010; Boger, 2011; Goodge and Fanning, 2010, 2016), have been used as the basis for extrapolating high heat flow values reported for the CAHFP into East Antarctica (Carson et al., 2014). To date, no direct constraint on terrestrial heat flow has been provided for this area of Wilkes Land, and how far south toward Dome $\mathrm{C}$ and the upper Aurora and Wilkes subglacial basins this province may extend is not clear. However, the data reported here indicate that areas of west-central East Antarctica at least as far north as $80^{\circ} \mathrm{S}$ may best be characterized as having only modest heat production.

\subsection{Heat flow}

Geothermal heat flow can be estimated from the empirical relation with crustal heat production (Lachenbruch, 1968; Roy et al., 1968). In the absence of direct terrestrial heat flow measurements, as is the case for Antarctica, it is possible to calculate heat flow from heat production by assuming the thickness of the upper crustal heat-producing layer (Sandiford and McLaren, 2002; Turcotte and Schubert, 2014). This thickness, $h_{\mathrm{r}}$, is the length scale for a decrease in $H_{\mathrm{O}}$ with depth in the upper crust (where most heat-producing elements are concentrated) and is determined from the slope of the function linking heat flow and heat production $(q-H)$. Although $H_{\mathrm{O}}$ is thought to decrease exponentially with depth (Lachenbruch, 1968), a first-order estimate of terrestrial heat flow can be obtained from

$q_{\mathrm{o}}=q_{\mathrm{m}}+q_{\mathrm{r}}+\left(H_{\mathrm{o}} h_{\mathrm{r}}\right)$,

where $q_{\mathrm{o}}$ is the surface heat flow $\left(\mathrm{mW} \mathrm{m}^{-2}\right), q_{\mathrm{m}}$ is the mantle heat flow, $q_{\mathrm{r}}$ is the "reduced" heat flow contributed by heat production in the middle and lower crust, and other terms are as defined above. For stable Precambrian continental crust, average values for $q_{\mathrm{m}}$ are about $14 \mathrm{~mW} \mathrm{~m}^{-2}$ and $q_{\mathrm{r}}$ is about $15 \mathrm{~mW} \mathrm{~m}^{-2}$ (Sandiford and McLaren, 2002; Perry et al., 2006; Lévy et al., 2010; Mareschal and Jaupart, 2013; Jaupert et al., 2016). Based on similarities in age and thickness to the Canadian and Scandinavian shields, a value of $7.3 \mathrm{~km}$ for $h_{\mathrm{r}}$ is used here. Using the relationship above and heat production results, the surface terrestrial heat flow is estimated from the igneous clast population to range from about $31-84 \mathrm{~mW} \mathrm{~m}^{-2}$ (Table 1), with an average of $48.0 \pm 13.6 \mathrm{~mW} \mathrm{~m}^{-2}$ ( $1 \sigma$ standard deviation; Fig. 5). The average value may be regarded as an integrated estimate of heat flow across the area of erosion within the catchment, but it is probably a maximum because it is derived from values of heat production that are biased toward crustal granites.

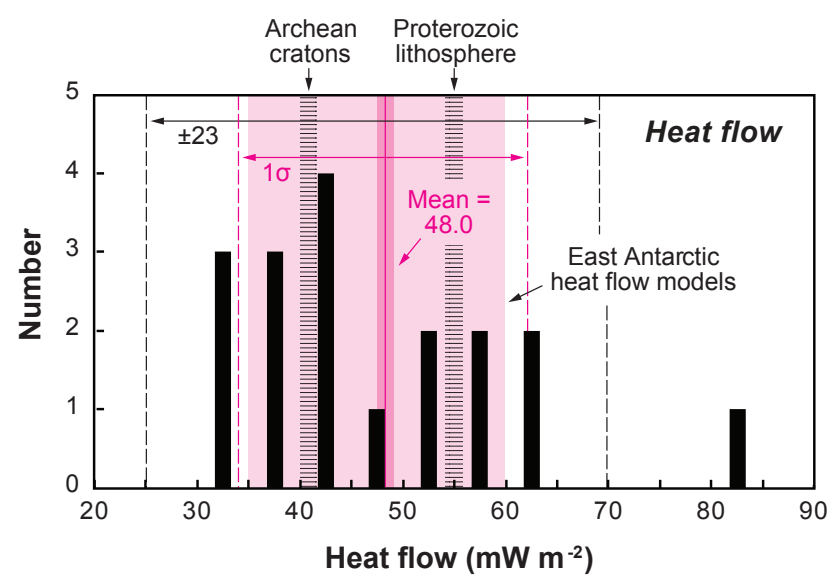

Figure 5. Histogram of heat flow values estimated from heat production in the glacial clasts. Mean value (magenta) is $48.0 \mathrm{~mW} \mathrm{~m}^{-2}$ $(n=18)$ with a $1 \sigma$ standard deviation of $13.6 \mathrm{~mW} \mathrm{~m}^{-2}$. Consideration of uncertainties in calculation of heat flow indicates an overall uncertainty of about $\pm 21 \mathrm{~mW} \mathrm{~m}^{-2}$ (see text). Range of heat flow values modeled for East Antarctica are shown for comparison (light pink; Van Liefferinge and Pattyn, 2013). Global average values for Archean cratons and Proterozoic lithosphere are shown by ruled bars (Nyblade et al., 1999).

\subsection{Uncertainties}

Because estimates of heat flow are used in ice-sheet models, it is important to consider uncertainties in the values used as input parameters. Here I consider uncertainties in the estimates of heat production and heat flow provided above.

\subsubsection{Uncertainties in $H_{0}$}

Laboratory precision on elemental analyses is very high (instrumental precision within $0.2 \%$ for $\mathrm{K}_{2} \mathrm{O}$ by XRF and within $2 \%$ for $\mathrm{U}$ and Th by ICPMS), density is assumed, and constants of heat production for various elements are assumed. Therefore, individual uncertainties for $H_{\mathrm{o}}$ were not calculated because they are expected to be very low relative to other parameters involved in the calculation of heat flow.

\subsubsection{Uncertainties in $q_{0}$}

Uncertainties in the linear relationship used to calculate surface heat flow $\left(q_{\mathrm{o}}\right)$ can be modeled using the following expression:

$\Delta q_{\mathrm{o}}=\Delta q_{\mathrm{m}}+\Delta q_{\mathrm{r}}+\left(\bar{H}_{\mathrm{o}} \Delta h_{\mathrm{r}}\right)+\left(\bar{h}_{\mathrm{r}} \Delta H_{\mathrm{o}}\right)$,

where $\Delta q_{\mathrm{o}}$ is the sum of uncertainties represented by the variables included in Eq. (3). Determining reasonable values for most of the $\Delta$ terms is problematical because the corresponding terms in the heat-flow equation are either based on model-derived values or are simply poorly constrained by limited empirical data. Because geological and seismological data indicate that East Antarctica is a stable craton, 
we can use typical cratonic values for $q_{\mathrm{m}}$ and $q_{\mathrm{r}}$ as a basis for evaluating uncertainty in these terms. For this analysis, $\Delta \mathrm{q}_{\mathrm{m}}$ is taken to be $\pm 2.5 \mathrm{~mW} \mathrm{~m}^{-2}$ based on a compilation of estimates worldwide for stable continental shield areas that range mostly from 12 to $17 \mathrm{~mW} \mathrm{~m}^{-2}$ (Mareschal and Jaupart, 2013; Jaupart et al., 2016). Uncertainty in the lower-crustal term, $\Delta q_{\mathrm{r}}$, is taken to be $3.0 \mathrm{~mW} \mathrm{~m}^{-2}$, assumed as a general variance $( \pm 20 \%)$ around a representative value of $15 \mathrm{~mW} \mathrm{~m}^{-2}$ for lower-crustal heat flow. A mean value of $\bar{H}_{\mathrm{o}}=2.6 \mu \mathrm{W} \mathrm{m}{ }^{-3}$ is used from the data reported here and the representative average value of $\bar{h}_{\mathrm{r}}=7.3 \mathrm{~km}$ that was used to calculate heat flow is assumed here. Uncertainty in heat production, $\Delta H_{\mathrm{o}}$, is taken as a $1 \sigma$ standard deviation of the calculated values $\left(1.86 \mathrm{~mW} \mathrm{~m}^{-2}\right)$, and uncertainty in the length scale, $\Delta h_{\mathrm{r}}$, is assumed to be $1500 \mathrm{~m}( \pm 20 \%)$, corresponding to the magnitude of subglacial topographic relief along the transport direction within the glacial source area catchment. Based on these inputs, we can derive a general uncertainty for the surface heat flow term $\left(\Delta q_{\mathrm{o}}\right)$ of about $23 \mathrm{~mW} \mathrm{~m}^{-2}$ (Fig. 5). This is a large value compared to the nominal mean value of $48 \mathrm{~mW} \mathrm{~m}^{-2}$ obtained here, and it reflects large natural variability in lithosphere properties as well as few direct constraints on mantle heat flow, lower crustal heat flow, and the vertical distribution of heat-producing elements in continental crust. Of this estimated uncertainty, $24 \%$ is contributed by the $\Delta q_{\mathrm{m}}$ and $\Delta q_{\mathrm{r}}$ terms, and $76 \%$ is attributed to the multiplying effects of the thickness and uncertainty of the upper-crustal heat-producing layer $\left(\bar{h}_{\mathrm{r}}\right.$ and $\left.\Delta h_{\mathrm{r}}\right)$. Only $8 \%$ is contributed by $\Delta H_{\mathrm{O}}$ itself. Together, the large combined uncertainty is therefore contributed mainly by mantle heat flow, lower crustal heat flow, and the vertical distribution of heatproducing elements; conversely, estimates of upper crustal heat production from the glacial clast samples are not an important source of uncertainty. Nonetheless, the overall range in surface heat flow covered by this uncertainty is consistent with the range of values reported for other cratons, lending support to the idea that the recovered glacial clasts are indeed representative of heat flow known from typical Archean and Proterozoic shield areas. Despite the inherent large uncertainties, the first-order results can help to inform future ice-sheet modeling.

\section{Discussion}

The glacial igneous clasts sampled for this study indicate that upper crustal heat production for at least a part of central East Antarctica is in the range of $0.3-7.5 \mu \mathrm{W} \mathrm{m}^{-3}$, with an average value of $2.6 \pm 1.9 \mu \mathrm{W} \mathrm{m}^{-3}(n=18)$. Assuming typical values of mantle heat flux, lower-crustal heat flux, and an upper-crustal length factor appropriate for stable continental cratons, the derived heat production corresponds to an average surface heat flux of $48 \mathrm{~mW} \mathrm{~m}^{-2}$. This approach assumes typical cratonic values for mantle and lower-crustal contributions, which it is reasonable given what is known about East Antarctic lithosphere (e.g., An et al., 2015). The net upper crustal contribution to surface heat flow is therefore about $19 \mathrm{~mW} \mathrm{~m}^{-2}$. Although clasts eroded from the subglacial bedrock surface represent a close approach to a random sampling of continental crust in East Antarctica, it is certainly possible that other rocks buried more deeply beneath the glacial interface in the upper or middle crust may harbor high heat-producing elements. In such a case, the distribution of heat-producing elements with depth may yield a greater total crustal contribution to heat flow. Given a lack of specific constraints to the contrary, however, a conservative approach is to assume a distribution of heat-producing elements based on analysis and models from other similar cratons. Several lines of evidence indicate that upper continental crust in most cratons is dominated by granites (study of exposed basement, borehole data, seismology; Artemieva et al., 2017), which are unique in having high concentrations of heat-producing elements $\mathrm{U}$, Th, and $\mathrm{K}$ (Jaupart and Mareschal, 2003). This can yield an order of magnitude greater heat production compared to granulites, gabbros, and amphibolites of the middle and lower crust (Artemieva et al., 2017). In general, granites in the upper crust therefore provide the greatest contribution to surface heat flow. If the Mesoproterozoic and Paleoproterozoic granitic samples of this study are representative of upper continental crust in cratonic East Antarctica, they likely provide a significant crustal contribution to surface heat flow.

Despite a small sample size, the results here are considered to be representative of crust in central East Antarctica. Firstly, it is important to note that the collection process was as randomized as possible given the time limitations at each site. All igneous clasts with potential age and geochemical signature were sampled, providing a large composite sample set. Secondly, the samples screened for detailed petrologic analysis have a wide age distribution, are well characterized in terms of geochemistry and isotopic composition, and comprise distinct petrogenetic groups (see Goodge et al., 2017). That is, they are not cogenetic or derivative from one another but rather representative of heterogeneous crust. Thirdly, none of the clast ages are known from other areas of bedrock exposure in the Transantarctic Mountains or along the greater Wilkes Land margin, such that they appear to represent a heretofore unrecognized and unique cratonic igneous terrain. At a minimum, the results obtained from this sample suite apply to the source area indicated on Fig. 2. Extrapolation over a broader area is unconstrained but may include some or all of the greater Byrd Glacier drainage network, perhaps extending as far north as Dome C. Although the data provided in this study are thought to be representative of crust in the interior of west-central East Antarctica, it is not possible to resolve gradients in geothermal properties within the sampled drainage area. For example, a comparison of samples at sites MSA $(n=3)$ and LWA $(n=10)$ shows no discernable pattern in age, heat production, or heat flow. Given the lack of a higher sampling density, the small clast sample 
size, sample age variation, and heterogeneity of bedrock geology underlying the Transantarctic Mountains make it difficult to distinguish gradients in either heat production or heat flow across individual drainages.

The total surface heat flux is quite similar to the average heat flux of $53 \mathrm{~mW} \mathrm{~m}^{-2}$ from 13 cratonic shield provinces globally (Jaupart et al., 2016). Likewise, Nyblade and Pollack (1993) found average surface heat flow values of $42 \mathrm{~mW} \mathrm{~m}^{-2}$ for Archean provinces and $47 \mathrm{~mW} \mathrm{~m}^{-2}$ for Paleoproterozoic provinces, which represent a general depletion of heat-producing elements in continental crust with increasing age. The heat flow results obtained here are also similar to earlier estimates for East Antarctica determined by geophysical modeling and inversion of ice borehole temperature profiles, which indicate a broad region with low to moderate values of $50-60 \mathrm{~mW} \mathrm{~m}^{-2}$ (Shapiro and Ritzwoller, 2004; Fox Maule et al., 2005). An et al. (2015) used a 3-D S-wave velocity model to construct temperature profiles for Antarctic lithosphere, from which they derived an average surface heat flux of $47 \mathrm{~mW} \mathrm{~m}^{-2}$ for the Gamburtsev province. This is lower than the average of $57 \mathrm{~mW} \mathrm{~m}^{-2}$ proposed by Shapiro and Ritzwoller (2004) or East Antarctica but quite comparable to the estimate provided here.

Taken together, the heat production and surface heat flow values estimated for the glacial igneous clasts discussed here appear to be representative of typical Archean-Proterozoic cratonic lithosphere. As a group they are distinctly different from the regional pattern shown by anomalously warm Proterozoic crust in central Australia with average $q_{\mathrm{o}}=$ $80 \mathrm{~mW} \mathrm{~m}^{-2}$ (McLaren et al., 2003), which has been suggested to extend across the Wilkes Land margin of Antarctica based on Gondwana supercontinent reconstructions (Carson et al., 2014; Aitken et al., 2014). Despite general age similarities among some of the clast population with parts of the Gawler Craton, and basement age correlations that indicate continuity of Mawson-type crust into the Wilkes sector of East Antarctica (Goodge and Fanning, 2016), the proxy heat production determinations and heat flow estimates provided here suggest that central portions of the East Antarctic ice sheet are underlain by stable continental crust with quite normal thermal properties represented by average values of heat production of about $2.5 \mu \mathrm{W} \mathrm{m}{ }^{-3}$ and heat flow of about $50 \mathrm{~mW} \mathrm{~m}^{-2}$.

Estimates of terrestrial heat flow such as those provided here can also be used to assess the effect of heat flow on ice-sheet mass balance. For example, Pollard et al. (2005) evaluated the effect of varying heat flow regimes on icesheet behavior by modeling changes in Antarctic ice volume, ice-sheet surface elevation, and area of the base at its pressure-melting point as a function of differing heat-flow regimes. Their models used three different geothermal heat flow distributions: (a) a uniform heat flow of $37.7 \mathrm{~mW} \mathrm{~m}^{-2}$, representing typical values of Archean cratons; (b) a uniform heat flow of $75.4 \mathrm{~mW} \mathrm{~m}^{-2}$ to mimic Proterozoic lithosphere characterized by high crustal heat production; and (c) a spa-

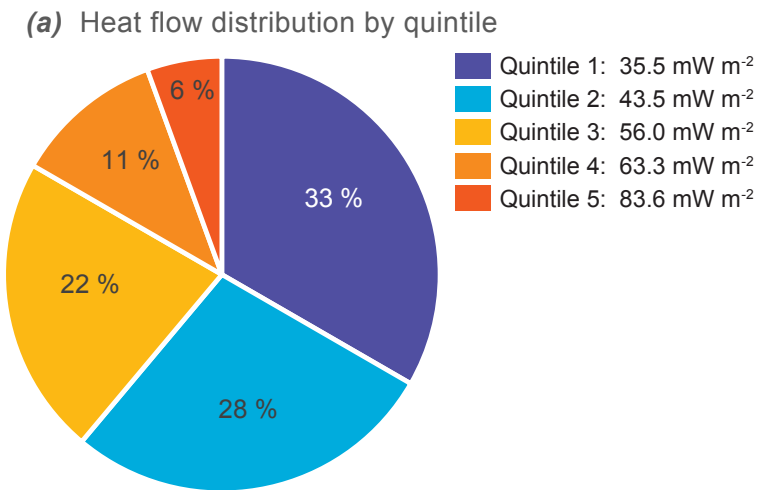

(b) Heat flow distribution by age group

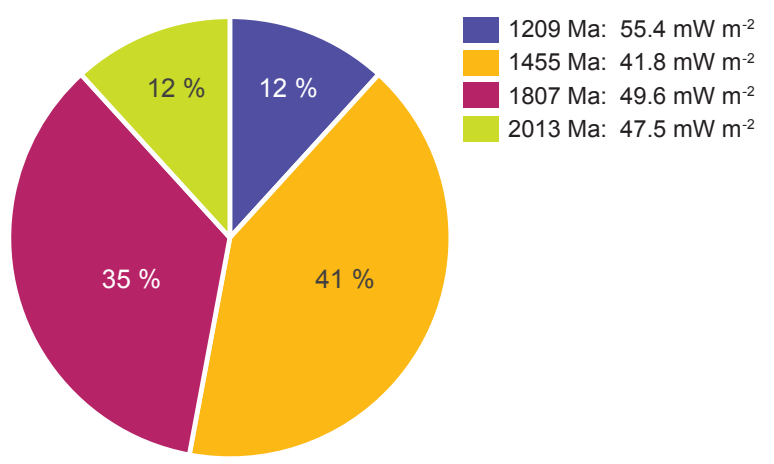

Figure 6. Pie charts summarizing distribution of heat flow estimates in this study. (a) Distribution of heat flow by quintiles between 30 and $80 \mathrm{~mW} \mathrm{~m}^{-2}$. Quintile averages are shown with the highest quintile represented by one sample with calculated heat flow of about $84 \mathrm{~mW} \mathrm{~m}^{-2}$. (b) Distribution of average heat flow by age groups. Values are shown in Table 2.

tially varying heat flow based on the distributions of different crustal provinces extrapolated from craton-margin geology and including values of 41 and $55 \mathrm{~mW} \mathrm{~m}^{-2}$ across most of East Antarctica. The values of heat production and heat flow estimated for central East Antarctica in this study are most consistent with their third approach: the average heat flow value of the Proterozoic granitoid samples is higher than in the case of uniform Archean lithosphere, yet lower than that assumed for Proterozoic lithosphere with high crustal heat production. Because the modeling of Pollard et al. (2005) shows a large effect of heat flow on the area of the ice-sheet base at its pressure-melting point, inputting appropriate values of crustal heat flow is vitally important for predicting, for example, the thermal and physical conditions of the basal ice-sheet regime.

To provide a simple model for the distribution of heat flow across the catchment area sampled in this study, mean heat flow values were calculated in two ways (Table 2). Firstly, the set of 18 samples was divided into equal quintiles representing ranges of $10 \mathrm{~mW} \mathrm{~m}^{-2}$ each. Average heat flow values were calculated for each quintile, as was a percentage of 
Table 2. Heat flow estimates in proportions based on quintile ranges and age.

\begin{tabular}{|c|c|c|c|c|c|c|c|}
\hline \multicolumn{4}{|c|}{ Binned by quintile } & \multicolumn{4}{|c|}{ Binned by age } \\
\hline Quintile & $\begin{array}{l}\text { Heat flow } \\
\left(\mathrm{mW} \mathrm{m}^{-2}\right)\end{array}$ & No. & $\%$ & $\begin{array}{l}\text { Age } \\
(\mathrm{Ma})\end{array}$ & $\begin{array}{l}\text { Heat flow } \\
\left(\mathrm{mW} \mathrm{m}^{-2}\right)\end{array}$ & No. & $\%$ \\
\hline 1 & 35.5 & 6 & 0.33 & 1209 & 55.4 & 2 & 0.12 \\
\hline 2 & 43.5 & 5 & 0.28 & 1455 & 41.8 & 7 & 0.41 \\
\hline 3 & 56.0 & 4 & 0.22 & 1770 & 49.6 & 6 & 0.35 \\
\hline 4 & 63.3 & 2 & 0.11 & 2013 & 47.5 & 2 & 0.12 \\
\hline 5 & 83.6 & 1 & 0.06 & & & & \\
\hline
\end{tabular}

the measurements falling in that range (Fig. 6a). Each quintile thus represents a proportionally based average heat flow value that could be used as an input for ice sheet models. Assuming that the igneous and metamorphic crust beneath the East Antarctic ice sheet is heterogeneous in age and composition, this proportional distribution of heat flow values may better reflect the complexities of crustal geothermal input as a function of subglacial area compared to a simple average. Secondly, the samples were grouped by age and average heat flow values calculated for each of four groups (Fig. 6b). This approach provides a reasonable estimate of heat flow potentially contributed by igneous crust that is proportionally represented by different age groups. Although the sample values were divided arbitrarily into five groups using the first method, this approach shows that about $61 \%$ of the sample results are $<50 \mathrm{~mW} \mathrm{~m}^{-2}$ (also indicated by the skewed distribution of values in Fig. 5), indicating that the bulk of crust underlying the East Antarctic ice sheet has a relatively low long-range average heat flow. The second approach, perhaps more useful from a modeling perspective because it groups samples by age, illustrates that for individual age groups the values are also quite modest, ranging from about 42 to $55 \mathrm{~mW} \mathrm{~m}^{-2}$, and are similar to the total group average. It is noteworthy that this range is nearly identical to the heterogeneous heat-flow model adopted by Pollard et al. (2005), appearing to validate the earlier study. Future ice-sheet stability modeling combined with the estimates of low to intermediate subglacial heat flow found in this study may thus help to further refine predictions of ice-sheet behavior.

\section{Conclusions}

Based on geochemical analysis of a suite of glacially eroded granitic rock clasts, the average heat production from an inferred large Proterozoic igneous crustal province in central East Antarctica is estimated to be about $2.5 \mu \mathrm{W} \mathrm{m}{ }^{-3}$, and the corresponding average surface heat flow is about $48 \mathrm{~mW} \mathrm{~m}^{-2}$. These geothermal properties are quite similar to average Archean and Proterozoic cratonic shields globally, despite being biased here to granitic compositions. Although the source of the granite clasts is not precisely known, they were likely derived from a region extending into central East Antarctica from near the inlet to Byrd Glacier. This region contrasts with other areas marked by high heat flow, such as the Central Australia Heat Flow Province and some parts of East Antarctica near Prydz Bay, indicating that crust in those areas likely does not extend into central regions of the continental interior.

Heat flow as estimated in this study is valuable for several reasons. Firstly, the values obtained here are similar to an estimate of heat flow derived by modeling of a borehole temperature profile near Dome $\mathrm{C}\left(54 \mathrm{~mW} \mathrm{~m}^{-2}\right.$; Fischer et al., 2013), helping to validate the earlier model finding. Likewise, they are consistent with the general range of values indicated by inversion of geophysical data from cratonic East Antarctica (e.g., Shapiro and Ritzwoller, 2004; Fox Maule et al., 2005; An et al., 2015). The average value of heat flow determined in this study $\left(48 \mathrm{~mW} \mathrm{~m}^{-2}\right)$ is quite similar to that obtained by An et al. (2015) from inversion of recent highquality S-wave data in central East Antarctica $\left(47 \mathrm{~mW} \mathrm{~m}^{-2}\right)$. More specifically, the values obtained here show a similar range to those indicated in the model derived from magnetic data (Fox Maule et al., 2005); both studies indicate that lithologic and, therefore, geothermal variations are real. Secondly, the new data provide a unique estimate of heat production and terrestrial heat flow that can be used as an input to ice-sheet stability models. In particular, they validate the general approach by Pollard et al. (2005) in which basal heat flow is varied by area depending on age and character of the subglacial geology. There is similar variability within this sample group that probably reflects the lithologic heterogeneity that is expected in continental shields. Thirdly, although the data presented here provide a good approximation of both heat production and heat flow in an otherwise inaccessible region of East Antarctica, the existing uncertainties associated with extrapolating heat flow from heat production illustrate the critical need for precise in situ measurements of terrestrial heat flow from the subglacial environment. One attempt at this beneath the Whillans Ice Stream in West Antarctica (Fisher et al., 2015) measured a heat flux of $285 \mathrm{~mW} \mathrm{~m}^{-2}$. This extraordinarily high value, even greater than that observed on modern ocean ridges (typically $\sim 100-250 \mathrm{~mW} \mathrm{~m}^{-2}$ near the ridge axis and one-third 
of that for oceanic crust $>50 \mathrm{Ma}$; Stein, 1995), likely is perturbed by advective heat transfer associated with subglacial flow of water and is therefore not representative of terrestrial heat flow in West Antarctica. A more recent measurement of $88 \mathrm{~mW} \mathrm{~m}^{-2}$ obtained in subglacial sediment near the grounding zone of the Whillans Ice Stream provides a better constraint on geothermal heat flow in West Antarctica and contrasts with estimates for cratonic East Antarctica (Begeman et al., 2017). Despite the difficulty in obtaining reliable heat flow data from the subglacial environment, it should be a high research priority and can be addressed by drilling through the ice sheets at as many sites as possible in order to assess crustal heterogeneity. Lastly, these estimates of low to moderate crustal heat flow indicate that some large regions of the interior East Antarctic ice sheet may be expected to be frozen at the bed, which is of use to future drilling projects that plan to intersect the glacial bed.

Sample availability. Samples referred to in this study are housed at the University of Minnesota Duluth and available on request to the author.

Data availability. Data supporting the conclusions are listed in Table 1.

Competing interests. The author declares that he has no conflict of interest.

Acknowledgements. Field and analytical portions of this project were supported by the National Science Foundation (award 0944645). Jacqueline Halpin and Jean-Claude Mareschal provided helpful feedback on the approach to estimating heat production and heat flow, and Jeff Severinghaus kindly reviewed an earlier draft manuscript. John Swenson generously provided insight into the treatment of uncertainties.

Edited by: Olaf Eisen

Reviewed by: two anonymous referees

\section{References}

Aitken, A. R. A., Young, D. A., Ferraccioli, F., Betts, P. G., Greenbaum, J.S., Richter, T. G., Roberts, J. L., Blankenship, D. D., and Siegert, M. J.: The subglacial geology of Wilkes Land, East Antarctica, Geophys. Res. Lett., 41, 2390-2400, https://doi.org/10.1002/2014GL059405, 2014.

An, M., Wiens, D.A., Zhao, Y., Feng, M., Nyblade, A., Kanao, M., Li, Y., Maggi, A., and Lèvêque, J.-J.: Temperature, lithosphereasthenosphere boundary, and heat flux beneath the Antarctic Plate inferred from seismic velocities, J. Geophys. Res.-Sol. Ea., 120, 8720-8742, https://doi.org/10.1002/2015JB011917, 2015.
Artemieva, I. M., Thybo, H., Jakobsen, K., Sørensen, N. K., and Nielsen, L. S. K.: Heat production in granitic rocks: Global analysis based on a new data compilation GRANITE2017, Earth Sci. Rev., 172, 1-26, 2017.

Begeman, C. B., Tulaczyk, S. M., and Fisher, A. T.: Spatially variable geothermal heat flux in West Antarctica: Evidence and implications, Geophys. Res. Lett., 44, 9823-9832, https://doi.org/10.1002/2017GL075579, 2017.

Bo, S., Siegert, M. J., Mudd, S. M., Sugden, D., Fujita, S., Xiangbin, C., Yunyun, J., Xueyuan, T., and Yuansheng, L.: The Gamburtsev Mountains and the origin and early evolution of the Antarctic Ice Sheet, Nature, 459, 690-693, https://doi.org/10.1038/nature08024, 2009.

Boger, S. D.: Antarctica - Before and after Gondwana, Gondwana Res., 19, 335-371, https://doi.org/10.1016/j.gr.2010.09.003, 2011.

Carson, C. J. and Pittard, M.: A reconnaissance crustal heat production assessment of the Australian Antarctic Territory (AAT), Geoscience Australia Record, Report 2012-63, 2012.

Carson, C. J., McLaren, S., Roberts, J. L., Boger, S. D., and Blankenship, D. D.: Hot rocks in a cold place: high sub-glacial heat flow in East Antarctica, J. Geol. Soc. London, 171, 9, https://doi.org/10.1144/jgs2013-030, 2014.

Davidson, J. P., McMillan, N. J. M., Moorbath, S., Wörner, G., Harmon, R. S., and López-Escobar, L.: The Nevados de Payachata volcanic region (18S/69W, N. Chile) II. Evidence for widespread crustal involvement in Andean magmatism, Contrib. Mineral. Petr., 105, 412-432, 1990.

Davidson, J. P., Harmon, R. S., and Wörner, G.: The source of central Andean magmas: Some considerations, in: Andean Magmatism and Its Tectonic Setting, edited by: Harmon, R. S. and Rapela, C. W., Geological Society of America Special Paper, 265, 233-244, 1991.

DeConto, R. M. and Pollard, D.: Rapid Cenozoic glaciation of Antarctica induced by declining atmospheric $\mathrm{CO}_{2}$, Nature, 421 , 245-249, https://doi.org/10.1038/nature01290, 2003.

Fischer, H., Severinghaus, J., Brook, E., Wolff, E., Albert, M., Alemany, O., Arthern, R., Bentley, C., Blankenship, D., Chappellaz, J., Creyts, T., Dahl-Jensen, D., Dinn, M., Frezzotti, M., Fujita, S., Gallee, H., Hindmarsh, R., Hudspeth, D., Jugie, G., Kawamura, K., Lipenkov, V., Miller, H., Mulvaney, R., Parrenin, F., Pattyn, F., Ritz, C., Schwander, J., Steinhage, D., van Ommen, T., and Wilhelms, F.: Where to find 1.5 million yr old ice for the IPICS “Oldest-Ice" ice core, Clim. Past, 9, 2489-2505, https://doi.org/10.5194/cp-9-2489-2013, 2013.

Fisher, A. T., Mankoff, K. D., Tulaczyk, S. M., Tyler, S. W., Foley, N., and the WISSARD Science Team: High geothermal heat flux measured below the West Antarctic Ice Sheet, Science Advances, 1, 1-9, https://doi.org/10.1126/sciadv.1500093, 2015.

Fox Maule, C., Purucker, M. E., Olsen, N., and Mosegaard, K.: Heat flux in Antarctica revealed from satellite magnetic data, Science, 309, 464-467, https://doi.org/10.1126/science.1106888, 2005.

Frost, B. R., Barnes, C. G., Collins, W. J., Arculus, R. J., Ellis D. J., and Frost, C. D.: A geochemical classification for granitic rocks, J. Petrol., 42, 2033-2048, https://doi.org/10.1093/petrology/42.11.2033, 2001.

Goodge, J. W. and Fanning, C. M.: Composition and age of the East Antarctic Shield in eastern Wilkes Land determined by proxy from Oligocene-Pleistocene glaciomarine sediment and Beacon 
Supergroup sandstones, Antarctica, Geol. Soc. Am. Bull., 122, 1135-1159, https://doi.org/10.1130/B30079.1, 2010.

Goodge, J. W. and Fanning, C. M.: Mesoarchean and Paleoproterozoic history of the Nimrod Complex, central Transantarctic Mountains, Antarctica: Stratigraphic revisions and relation to the Mawson Continent in East Gondwana, Precambrian Res., 285, 242-271, https://doi.org/10.1016/j.precamres.2016.09.001, 2016.

Goodge, J. W. and Finn, C. A.: Glimpses of East Antarctica: Aeromagnetic and satellite magnetic view from the central Transantarctic Mountains of East Antarctica, J. Geophys. Res., 115, B09103, https://doi.org/10.1029/2009JB006890, 2010.

Goodge, J. W., Fanning, C. M., and Bennett, V. C.: U-Pb evidence of $\sim 1.7 \mathrm{Ga}$ crustal tectonism during the Nimrod Orogeny in the Transantarctic Mountains, Antarctica: implications for Proterozoic plate reconstructions, Precambrian Res., 112, 261-288, https://doi.org/10.1016/S0301-9268(01)00193-0, 2001.

Goodge, J. W., Vervoort, J. D., Fanning, C. M., Brecke, D. M., Farmer, G. L., Williams, I. S., Myrow, P. M., and DePaolo, D. J.: A positive test of East Antarctica-Laurentia juxtaposition within the Rodinia supercontinent, Science, 321, 235-240, https://doi.org/10.1126/science.1159189, 2008.

Goodge, J. W., Fanning, C. M., Brecke, D. M., Licht, K. J., and Palmer, E. F.: Continuation of the Laurentian Grenville province in western East Antarctica, J. Geol., 118, 601-619, https://doi.org/10.1086/656385, 2010.

Goodge, J. W., Fanning, C. M., Vervoort, J. D., and Radakovich, A. L.: More SWEAT: Discovery of Mesoproterozoic and Paleoproterozoic igneous crust in East Antarctica strengthens the case for Laurentia-Antarctica connections in Rodinia, Geological Society of America Abstracts with Programs, 44, p. 599, 2012.

Goodge, J. W., Fanning, C. M., Fisher, C. M., and Vervoort, J. D.: Proterozoic crustal evolution of central East Antarctica: Age and isotopic evidence from glacial igneous clasts, and links with Australia and Laurentia, Precambrian Res., 299, 151-176, https://doi.org/10.1016/j.precamres.2017.07.026, 2017.

Govindaraju, K.: Compilation of working values and sample description for 383 geostandards, Geostandards Newsletter, 18, 1-158, https://doi.org/10.1046/j.1365-2494.1998.53202081.xi1, 1994 .

Haenel, R., Rybach, L., and Stegena L. (Eds.): Handbook of Terrestrial Heat-Flow Density Determination: Dordrecht, Kluwer Academic Publishers, 486 pp., 1988.

Hasterok, D. and Chapman, D. S.: Heat production and geotherms for the continental lithosphere, Earth Planet. Sc. Lett., 307, 5970, https://doi.org/10.1016/j.epsl.2011.04.034, 2011.

Jamieson, S. S. R. and Sugden, D. E.: Landscape Evolution of Antarctica, in: Antarctica: A Keystone in a Changing World (Proceedings of the 10th International Symposium on Antarctic Earth Sciences), edited by: Cooper, A. K., Barrett, P. J., Stagg, H., Storey, B., Stump, E., and Wise, W., Washington, DC, The National Academies Press, 2008.

Jaupart, C. and Mareschal, J.-C.: Constraints on crustal heat production from heat flow data, in: Treatise on Geochemistry, edited by: Rudnick, R. L., Elsevier-Pergamon, Oxford, 3, 65-84, https://doi.org/10.1016/B0-08-043751-6/03017-6, 2003.

Jaupart, C., Mareschal, J.-C., and Iarotsky, L.: Radiogenic heat production in the continental crust, Lithos, 262, 398-427, https://doi.org/10.1016/j.lithos.2016.07.017, 2016.
Kemp, A. I. S. and Hawkesworth, C. J.: Granitic perspectives on the generation and secular evolution of the continental crust, in: Treatise on Geochemistry, edited by: Holland, $\mathrm{H}$. D. and Turekian, K. K., Amsterdam, Elsevier, 3, 349-410, https://doi.org/10.1016/B0-08-043751-6/03027-9, 2003.

Lachenbruch, A. H.: Preliminary geothermal model of the Sierra Nevada, J. Geophys. Res., 73, 6977-6989, 1968.

Lévy, F., Jaupart, C., Mareschal, J., Bienfait, G., and Limare, A.: Low heat flux and large variations of lithospheric thickness in the Canadian Shield, J. Geophys. Res., 115, B06404, https://doi.org/10.1029/2009JB006470, 2010.

Mareschal, J.-C. and Jaupart, C.: Radiogenic heat production, thermal regime and evolution of continental crust, Tectonophysics, 609, 524-534, https://doi.org/10.1029/2009JB006470, 2013.

McLaren, S., Sandiford, M., Hand, M., Neumann, N., Wyborn, L., and Bastrakova, I.: The hot southern continent: heat flow and heat production in Australian Proterozoic terranes, in: Evolution and Dynamics of the Australian Plate, edited by: Hillis, R. R. and Müller, R. D., Geological Society of Australia Special Publications, 12, 151-161, 2003.

Neumann, N., Sandiford, M., and Foden, J.: Regional geochemistry and continental heat flow: Implications for the origin of the South Australian heat flow anomaly, Earth Planet. Sc. Lett., 183, 107120,2000

Nissen, C. I., Fanning, C. M., and Goodge, J. W.: New evidence of Proterozoic metamorphic events in East Antarctica from insitu $\mathrm{U}-\mathrm{Pb}$ age dating of monazite in metamorphic glacial clasts, central Transantarctic Mountains, Antarctica, Geological Society of America Abstracts with Programs, 45, p. 798, 2013.

Nyblade, A. A.: Heat flow and the structure of Precambrian lithosphere, Lithos, 48, 81-91, 1999.

Nyblade, A. A. and Pollack, H. N.: A global analysis of heat flow from Precambrian terrains: implications for the thermal structure of Archean and Proterozoic lithosphere, J. Geophys. Res., 98, 12207-12218, 1993.

Oliver, R. L. and Fanning, M.: Antarctica: precise correlation of Paleoproterozoic terrains, in: The Antarctic Region: Geological Evolution and Processes, edited by: Ricci, C. A., Terra Antarctica Publications, Siena, 163-172, 1997.

Perry, H., Rosieanu, C., Mareschal, J. C., and Jaupart, C.: Thermal regime of the lithosphere in Canada, Can. J. Earth Sci., 47, 389408, https://doi.org/10.1139/E09-059, 2010.

Peucat, J.-J., Capdevila, R., Fanning, C. M., Ménot, R.-P., Pécora, L., and Testut, L.: $1.60 \mathrm{Ga}$ felsic volcanic blocks in the moraines of the Terre Adélie craton, Antarctica: Comparisons with the Gawler Range volcanics, South Australia, Aust. J. Earth Sci., 49, 831-845, https://doi.org/10.1046/j.1440-0952.2002.00956.x, 2002.

Pollard, D. and DeConto, R. M.: Modeling West Antarctic ice sheet growth and collapse through the past five million years, Nature, 458, 329-332, https://doi.org/10.1038/nature07809, 2009.

Pollard, D., DeConto R. M., and Nyblade, A. A.: Sensitivity of Cenozoic Antarctic ice sheet variations to geothermal heat flux, Global Planet. Change, 49, 63-74, https://doi.org/10.1016/j.gloplacha.2005.05.003, 2005.

Purucker, M. E.: Antarctica Basal Heat Flux, available at: http: //websrv.cs.umt.edu/isis/index.php/Antarctica_Basal_Heat_Flux (last access: 2 February 2018), 2012. 
Rignot, E., Mouginot, J., and Scheuchl, B.: Ice flow of the Antarctic ice sheet, Science, 333, 1427-1430, https://doi.org/10.1126/science.1208336, 2011.

Rose, K. C., Ferraccioli, F., Jamieson, S. S. R., Bell, R. E., Corr, H., Creyts, T. T., Braaten, D., Jordan, T. A., Fretwell, P. T., and Damaske, D.: Early East Antarctic Ice Sheet growth recorded in the landscape of the Gamburtsev Subglacial Mountains, Earth Planet. Sc. Lett., 375, 1-12, https://doi.org/10.1016/j.epsl.2013.03.053, 2013.

Roy, R. F., Blackwell, D. D., and Birch, F.: Heat generation of plutonic rocks and continental heat flow provinces, Earth Planet. Sc. Lett., 5, 1-12, 1968.

Rudnick, R. L. and Fountain, D. M.: Nature and composition of the continental crust: a lower crustal perspective, Rev. Geophys., 33, 267-309, 1995.

Rybach, L.: Radioactive heat production in rocks and its relation to other petrophysical parameters, Pure Appl. Geophys., 114, 309317,1976

Rybach, L.: Determination of heat production rate, in: Handbook of Terrestrial Heat-Flow Density Determination, edited by: Haenel, R., Rybach, L., and Stegena, L., Kluwer Academic Publishers, Dordrecht, 125-142, 1988.

Sandiford, M. and McLaren, S.: Tectonic feedback and the ordering of heat producing elements within the continental lithosphere, Earth Planet. Sc. Lett., 204, 133-150, https://doi.org/10.1016/S0012-821X(02)00958-5, 2002.
Schroeder, D. M., Blankenship, D. D., Young, D. A., and Quartini, E.: Evidence for elevated and spatially variable geothermal flux beneath the West Antarctic Ice Sheet, P. Natl. Acad. Sci. USA, 111, 9070-9072, 2014.

Shapiro, N. M. and Ritzwoller, M. H.: Inferring surface heat flux distributions guided by a global seismic model: particular application to Antarctica, Earth Planet. Sc. Lett., 223, 213-224, 2004

Siegert, M. J.: Antarctic subglacial lakes, Earth-Sci. Rev., 50, 2950, 2000.

Stein, C.: Heat flow of the Earth, in: Global Earth Physics, edited by: Ahrens, T. J., American Geophysical Union, Washington, D.C., 144-158, https://doi.org/10.1029/RF001p0144, 1995.

Turcotte, D. L. and Schubert, G.: Geodynamics, Cambridge, Cambridge University Press, 623 pp., 2014.

Van Liefferinge, B. and Pattyn, F.: Using ice-flow models to evaluate potential sites of million year-old ice in Antarctica, Clim. Past, 9, 2335-2345, https://doi.org/10.5194/cp-9-23352013, 2013.

Whillans, I. M. and Cassidy, W. A.: Catch a falling star: Meteorites and old ice, Science, 222, 55-57, 1983.

Wörner, G., Moorbath, S., Horn, S., Entenmann, J., Harmon, R.S., Davidson, J., and López-Escobar, L.: Large- and fine-scale geochemical variations along the Andean arc of northern Chile $\left(17.5^{\circ}-22^{\circ} \mathrm{S}\right)$, in: Tectonics of the Southern Central Andes, Reutter, K. J., Scheuber, E., and Wigger, P. J., Springer, Berlin, Heidelberg, 77-92, 1994. 